\title{
Low Noise Cruise Efficient Short Take-Off and Landing Transport Vehicle Study
}

Hyun D. Kim, Jeffrey J. Berton, and Scott M. Jones

Glenn Research Center, Cleveland, Ohio 


\section{NASA STI Program . . . in Profile}

Since its founding, NASA has been dedicated to the advancement of aeronautics and space science. The NASA Scientific and Technical Information (STI) program plays a key part in helping NASA maintain this important role.

The NASA STI Program operates under the auspices of the Agency Chief Information Officer. It collects, organizes, provides for archiving, and disseminates NASA's STI. The NASA STI program provides access to the NASA Aeronautics and Space Database and its public interface, the NASA Technical Reports Server, thus providing one of the largest collections of aeronautical and space science STI in the world. Results are published in both non-NASA channels and by NASA in the NASA STI Report Series, which includes the following report types:

- TECHNICAL PUBLICATION. Reports of completed research or a major significant phase of research that present the results of NASA programs and include extensive data or theoretical analysis. Includes compilations of significant scientific and technical data and information deemed to be of continuing reference value. NASA counterpart of peer-reviewed formal professional papers but has less stringent limitations on manuscript length and extent of graphic presentations.

- TECHNICAL MEMORANDUM. Scientific and technical findings that are preliminary or of specialized interest, e.g., quick release reports, working papers, and bibliographies that contain minimal annotation. Does not contain extensive analysis.

- CONTRACTOR REPORT. Scientific and technical findings by NASA-sponsored contractors and grantees.
- CONFERENCE PUBLICATION. Collected papers from scientific and technical conferences, symposia, seminars, or other meetings sponsored or cosponsored by NASA.

- SPECIAL PUBLICATION. Scientific, technical, or historical information from NASA programs, projects, and missions, often concerned with subjects having substantial public interest.

- TECHNICAL TRANSLATION. Englishlanguage translations of foreign scientific and technical material pertinent to NASA's mission.

Specialized services also include creating custom thesauri, building customized databases, organizing and publishing research results.

For more information about the NASA STI program, see the following:

- Access the NASA STI program home page at http://www.sti.nasa.gov

- E-mail your question via the Internet to help@sti.nasa.gov

- Fax your question to the NASA STI Help Desk at 301-621-0134

- Telephone the NASA STI Help Desk at 301-621-0390

- Write to: NASA Center for AeroSpace Information (CASI) 7115 Standard Drive Hanover, MD 21076-1320 
NASA/TM-2007-214659

AIAA-2006-7738

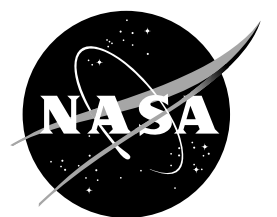

\section{Low Noise Cruise Efficient Short Take-Off and Landing Transport Vehicle Study}

Hyun D. Kim, Jeffrey J. Berton, and Scott M. Jones

Glenn Research Center, Cleveland, Ohio

Prepared for the

Sixth Aviation Technology, Integration and Operations Conference (ATIO)

sponsored by the American Institute of Aeronautics and Astronautics

Wichita, Kansas, September 25-27, 2006

National Aeronautics and

Space Administration

Glenn Research Center

Cleveland, Ohio 44135 


\section{Acknowledgments}

The authors would like to express their thanks to Ronald Kawai and Sean Wakayama at Boeing Technology/Phantom Works and James Stone and Eugene Krejsa at Diversitech, Inc., for their contributions to this CESTOL study.

Trade names and trademarks are used in this report for identification only. Their usage does not constitute an official endorsement, either expressed or implied, by the National Aeronautics and Space Administration.

This work was sponsored by the Fundamental Aeronautics Program at the NASA Glenn Research Center.

Level of Review: This material has been technically reviewed by technical management.

Available from

NASA Center for Aerospace Information 7115 Standard Drive

Hanover, MD 21076-1320
National Technical Information Service 5285 Port Royal Road Springfield, VA 22161 


\title{
Low Noise Cruise Efficient Short Take-Off and Landing Transport Vehicle Study
}

\author{
Hyun D. Kim, Jeffrey J. Berton, and Scott M. Jones \\ National Aeronautics and Space Administration \\ Glenn Research Center \\ Cleveland, Ohio 44135
}

\begin{abstract}
The saturation of the airspace around current airports combined with increasingly stringent community noise limits represents a serious impediment to growth in world aviation travel. Breakthrough concepts that both increase throughput and reduce noise impacts are required to enable growth in aviation markets. Concepts with a 25 year horizon must facilitate a $4 \mathrm{x}$ increase in air travel while simultaneously meeting community noise constraints. Attacking these horizon issues holistically is the concept study of a Cruise Efficient Short Take-Off and Landing (CESTOL) high subsonic transport under the NASA's Revolutionary Systems Concepts for Aeronautics (RSCA) project. The concept is a high-lift capable airframe with a partially embedded distributed propulsion system that takes a synergistic approach in propulsion-airframe-integration (PAI) by fully integrating the airframe and propulsion systems to achieve the benefits of both low-noise short take-off and landing (STOL) operations and efficient high speed cruise. This paper presents a summary of the recent study of a distributed propulsion/airframe configuration that provides low-noise STOL operation to enable 24-hour use of the untapped regional and citycenter airports to increase the capacity of the overall airspace while still maintaining efficient high subsonic cruise flight capability.
\end{abstract}

\section{Nomenclature}

$B P R \quad$ bypass ratio, bypass flow rate divided by core flow rate, dimensionless

$B W B \quad$ blended-wing-body

CESTOL cruise efficient short take-off and landing

$C_{j} \quad$ jet momentum coefficient

$C_{\text {Lmax }} \quad$ maximum lift coefficient

$E B F \quad$ externally blown flap

$E P N L \quad$ effective perceived noise level, EPNdB

$G R C \quad$ NASA Glenn Research Center

$H P C \quad$ high pressure compressor

$I B F \quad$ internally blown flap

nmi nautical mile

OASPL overall sound pressure level, $\mathrm{dB}$ re $20 \mu \mathrm{Pa}$

$P N L \quad$ perceived noise level, $\mathrm{PNdB}$

$P N L T \quad$ tone-corrected perceived noise level, $\mathrm{PNdB}$

SFC specific fuel consumption, $\mathrm{lbm} / \mathrm{hr} / \mathrm{lbf}$

SNPR slot nozzle pressure ratio, dimensionless

$S P L$

STOL sound pressure level, $\mathrm{dB}$ re $20 \mu \mathrm{Pa}$

TOGW take-off gross weight, lb

USB upper surface blowing 


\section{Introduction}

Since the introduction of large subsonic jet powered transport aircraft such as the Boeing 707, the majority of these vehicles have been designed by placing thrust-generating engines in pods either under the wings or on the fuselage to minimize aerodynamic interactions on the vehicle operation. Figure 1 shows some early aircrafts with various propulsion system placements. The exceptions to this kind of configuration were the British De Havilland Comet aircraft, which was one of the first generation jet transports, and the Russian An-72/74. The Comet had all its engines buried in the thick wing root section but really never took advantage of the full benefits of integrating two distinct systems, i.e., the propulsion system and wing. In addition, the embedded propulsion system caused maintenance difficulties due to its engine placement within the wing structure and low reliability of the first generation jet engines of the 1950s. A modern version of the Comet continues to fly reconnaissance missions as the BAe Nimrod. The An-74 was an Upper Surface Blowing (USB) Short Take-Off and Landing (STOL) regional transport designed for unprepared fields and operated by Aeroflot. On this aircraft, the engines were mounted on the top of the wing so that the engine exhausts were blown on the upper surface of the wing to obtain high lift.

Aside from the conventional tube fuselage type vehicles, there were flying wing aircrafts such as the Northrop YB-49 and more recent B-2 bomber for the military that had all the engines buried in the wing. In particular, the YB-49, which was flown in the 1940's, had four linearly arranged engines in each side of wing with subsonic rectangular inlets and conventional circular nozzles at each side of the wing leading edges and trailing edges, respectively. In 1977, a new flying wing concept was patented and provided additional innovations to the current distributed propulsion concept. ${ }^{1}$ This design had inlets and nozzles along the wing leading and trailing edges, respectively, and buried engines in the wing, providing a completely distributed thrust for the vehicle from the wing tip to tip.

In early 1970s, NASA conducted extensive studies on STOL vehicles addressing noise and traffic congestion problems due to continued growth in air traffic and the growth of commercial and residential developments. In particular, NASA's research and developments on STOL technology aimed at 95 PNdB on a 500$\mathrm{ft}$ sideline as a figure of merit. ${ }^{2}$

To address some of the shortfalls associated with these aircraft configurations, new propulsion-airframe integrated vehicle concepts based on distributed propulsion systems were investigated. ${ }^{3}$ Recognizing synergistic benefits associated with distributed propulsion and airframe integration, a system study of a high subsonic cruise speed, low noise STOL vehicle configuration was conducted under the NASA's Revolutionary System Concept in Aeronautics (RSCA) project to explore the potential benefits from incorporating embedded distributed propulsion systems into a cruise efficient airplane in order to enable quiet operations from regional airports. For this study, the time frame of year 2025 was selected and the vehicle including engine selection was configured to represent corresponding future technology maturation.

\section{Study Approach}

Continuing air traffic growth is forecasted by many organizations and agencies. Fig. 2(a) shows the Boeing air traffic growth forecast for the next 20 years. ${ }^{4}$ Historically, air travel as a discretionary item has had growth as a multiple of Gross Domestic Product (GDP). With continuing increase in GDP, extrapolating beyond 2025 would result in a future $4 \mathrm{X}$ increase in air travel. Since population is increasing with economic growth, continuing growth in the passenger and freight air traffic will need to better distribute the departure and destinations using available airport assets. A significant deterrent that is occurring, as shown in Fig. 2(b), is the exponential rise in noise rules, regulations and restrictions. ${ }^{4}$ In order to meet future traffic demand, revolutionary airplane concepts are needed to provide a dramatic reduction in airport vicinity noise while operating with transcontinental range from short airfields. Fig. 3 shows the US airport distribution with respect to actual runway length. ${ }^{5}$ Use of transport aircraft at smaller airports should maintain a reasonable runway width to allow turnarounds and lateral dispersion for

landing in cross winds. Setting a $100 \mathrm{ft}$. minimum width at civil airports reduces the total but there are still 973 of which $84 \%$ or 813 airports have runway lengths of $5000 \mathrm{ft}$. or longer.

The concept should be able to cruise at Mach 0.8 in order to operate in transcontinental airspace. Further recognizing the need for revolutionary propulsion integration, this study focused on the use of embedded distributed propulsion for very low noise STOL capability with highly efficient cruise performance. This report summarizes the 
results of a study on conceptual airplane for the 2025+ time frame with very low noise design features that could operate around the clock from untapped regional airspace. A review of past studies and related reports was conducted to determine the most suitable concepts for reducing take-off and landing field lengths. For the vehicle configuration, the Blended-Wing-Body (BWB) type of airplane ${ }^{6}$ was selected for its efficient cruise capability and large internal volume for embedding distributed multiple engines. Other studies also have identified that the BWB configuration is beneficial for forward noise shielding and no aft noise reflections. ${ }^{7-10}$

Recent literature was used to conceive a potentially quiet STOL concept using embedded distributed propulsion. Numerous studies and investigations of turbofan-powered STOL airplanes were conducted during the 1970's and 1980's leading into the Air Force prototype competition for the Advanced Medium STOL Transport (AMST). The Boeing YC-14 used upper surface blowing (USB) while the McDonnell-Douglas YC-15 used the relatively simple externally blow flap (EBF). The prototypes shown in Fig. 4 had straight wings for which cruise speed was below Mach 0.70. In the following competition for a production program, the McDonnell-Douglas C-17 with the relatively simple EBF on a swept wing won. Various investigations had shown that the most efficient powered lift system is the internally blown flap (IBF) concept. Fig. 5 shows a number of various powered lift concepts at jet momentum coefficient of $\mathrm{C}_{\mathrm{j}}=2$ where the coefficient is jet thrust force divided by freestream dynamic pressure times wing area. ${ }^{11}$ While efficient, the previous studied IBF concept was judged to be complex due to the problem associated with hot gas being transferred in a long duct from the podded engines through main wing structure. The hot gas was to be blown at the wing trailing edge to increase circulation around the wing. However, the current distributed propulsion system using many small engines instead of a few large engines eliminates this hot ducting problem by diverting some of the low pressure 'cold' fan flow directly through short IBF ducts to the high aspect ratio slotted nozzle.

\section{Vehicle Configuration}

For the vehicle configuration study, Boeing Phantom Works performed the task under a NASA contract. ${ }^{12}$ As noted above, the initial configuration was based on the BWB because of its high cruise efficiency, low noise characteristics, and a large internal volume for integrating embedded distributed propulsion. The powered lift system was selected because of the highest efficiency of the IBF. Distributed propulsion with 12 small engines would enable using low pressure fan bypass diversion air that would not have the hot duct issues and be subsonic to keep the powered lift noise down. The revolutionary concept is the use of distributed embedded propulsion for quiet IBF powered lift with substantial engine noise shielding, including some jet noise shielding. The CESTOL concept combines substantial engine noise shielding with rapid climb out and steep descent to provide a very low noise footprint. Based on current trend in air transports and STOL consideration, the following mission requirements were established at the beginning of the study.

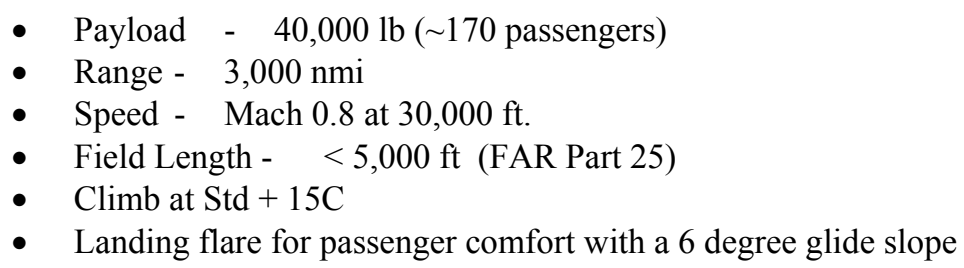

Using the Boeing WingMOD ${ }^{13}$ multidisciplinary optimization code, an aerodynamically trimmed vehicle configuration was obtained and is shown in Fig. 6. The sizing and mission performance data is shown in Table 1. The take-off field length is for obstacle clearance with an engine out. However, because many (12) engines are distributed on the wingspan near the trailing edge, the engine out condition did not include lateral control drag due to the fact that it should not cause any significant yawing moment at the mission critical stage for the operation of a STOL vehicle, mainly at vehicle take-off stage. Indeed, aircraft with powered lift distributed propulsion systems may require a general reexamination of engine-out airworthiness certification regulations because controllability limits are currently based on all engines out. Note that the landing field length is about 3,500 ft. which includes the 1.67 factor on stopping distance. It is believed that use of the variable area nozzle for improved powered lift during approach would enable shortening the field length. The take off flight profiles are shown in Fig. 7 for 150, 500, and 3,000 nautical miles. They are based on no power cut back and flap retraction and clean up at 3,000 ft. For minimum noise, depending on the footprint characteristics desired, other schedules could be used. 


\section{Engine Cycle Analysis}

The engine cycle analysis was based on projecting improvement in specific fuel consumption (SFC) into the 2025 time frame. Recognizing the challenges, the SFC for 2025 is used as a goal to have a small engine SFC level at current large engine levels. Each engine has about 7,000 lbs of thrust at sea level. SFC trends are shown in Fig. 8. The cruise SFC goal was set at 0.52 for Mach $0.80,35,000 \mathrm{ft}$ altitude. Similarly, the engine thrust to weight ratio goal was set based on current large engines but the weight was reduced $20 \%$ for the revolutionary concepts that are very short. For the vehicle configuration, Boeing selected an engine with bypass ratio $B P R=5.7$ and NASA GRC also provided engine data with higher $\mathrm{BPR}=9.4$. Using these two engine bypass ratios, preliminary vehicle noise analysis results were obtained by Stone, et al. ${ }^{14}$ and will be discussed in the following section.

For engine cycle analysis with BPR $=9.4$ performed by NASA GRC, engine performance was calculated using a Numerical Propulsion System Simulator (NPSS) ${ }^{15}$ model of a two-spool separate flow turbofan. The individual component technology assumptions were as follows: fan and high pressure compressor (HPC) polytropic efficiency each were $91 \%$, and high and low pressure turbine polytropic efficiency each was $93 \%$. A single-stage fan was assumed with a maximum pressure ratio of 2.0 in order to guarantee sufficient specific thrust, although the final cycle did not require such a high pressure ratio. The HPC pressure ratio was limited to 20 to keep stage count and engine length down. Fan diameter was limited to about 33 inches which limited engine airflow to about 200 $\mathrm{lbm} / \mathrm{s}$. A bypass ratio limit of 10 was imposed to keep core size within reasonable manufacturing limits for conventional separate flow turbofan architecture. Finally, at the Mach $0.80,35,000 \mathrm{ft}$. altitude flight condition there was a minimum thrust requirement of $1100 \mathrm{lb}$ as well as a maximum specific fuel consumption (SFC) of 0.52 $\mathrm{lbm} / \mathrm{hr} / \mathrm{lbf}$. Other than these assumptions, weight and aeromechanical design trades were not considered; furthermore, it was recognized that even with these assumptions a non-optimum engine cycle could result without a detailed engine design parameter study. It was also noted that the HPC pressure ratio limit may be too conservative for the study objectives but it was estimated that it would be sufficient to meet the target SFC. Based on these technology assumptions and since weight and mechanical design were not an issue, the HPC pressure ratio was always set to the maximum, 20, to obtain the highest overall pressure ratio for any given fan pressure ratio and thus the lowest possible SFC. Next, fan pressure ratio was required to be about 1.6 to achieve the minimum cruise thrust; in addition, the resulting takeoff thrust of about $7000 \mathrm{lb}$ was acceptable for the aircraft. Once fan and HPC pressure ratio were set, bypass ratio was investigated. Bypass ratio was increased to the limit since SFC decreases with increasing bypass ratio and it was found that the core retained adequate ability to power the fan even at this limit. It should be noted that engine thrust also decreased with increasing bypass ratio, but the thrust requirement was still met. Finally, the cycle maximum temperature of about $2740{ }^{\circ} \mathrm{R}$ was a fallout from the previous three design choices (fan pressure ratio, overall pressure ratio, and bypass ratio).

\section{Noise Analysis \& Results}

The embedded distributed propulsion enables the use of low pressure fan bypass diversion air for an IBF system, wherein a high aspect ratio slot nozzle is used in conjunction with a slotted airfoil with the nozzle exhaust pumping through the slot to increase circulation and lift. The STOL capability offers rapid climb and descent to reduce noise footprints. The small diameter engines have forward noise shielding and employ mixer nozzles to increase the jet noise frequency and move the jet noise source forward. The forward jet source noise can then be shielded by airframe surfaces to reduce aft and sideline noise. If deemed beneficial, the vertical control surfaces can also be positioned and sized to further reduce sideline noise. The configuration shown in Fig. 6 has 12 engines partially embedded in the upper wing surface. Half of the low pressure fan flow from each engine is diverted to the high aspect ratio slot nozzle. Boeing selected engines with bypass ratio BPR $=5.7$ and NASA also provided data for engines with $\mathrm{BPR}=9.4$. A more complete description of noise analysis methods and results can be found in Ref. 14.

It was found that the baseline airplane without noise suppression devices would produce a peak tonecorrected perceived noise level of 108.4 PNdB at take-off on the 500-ft sideline used in the STOL studies of the 1970 's, with a corresponding effective perceived noise level of 106.1 EPNdB. Mixing enhancement chevrons on the engine fan and core nozzle were found to provide significant benefit; the peak noise is reduced to $106.3 \mathrm{PNdB}$ and the EPNL is reduced to $103.4 \mathrm{EPNdB}$ on the $500-\mathrm{ft}$ sideline. PNLT time history comparison between with and without chevron nozzles for engine $\mathrm{BPR}=5.7$ is shown in Fig. 9(a). In comparison with the current FAR-36 measuring points, the sideline noise is 96.8 PNdB, 0.5 EPNdB below Stage 3; the flyover noise is 94.7 EPNdB, 2.6 
EPNdB below Stage 3; the approach noise is only 47.7 EPNdB, 53.3 EPNdB below Stage 3, but the prediction does not include turbomachinery noise, so it is likely to be considerably higher. So it is clear that such an airplane might well develop into an attractive product. One possibility is to increase engine bypass ratio from the BPR $=5.7$ baseline. Using engine $\mathrm{BPR}=9.4$, significant noise benefits were found; peak noise of $104.3 \mathrm{PNdB}$ and $\mathrm{EPNL}=$ 101.6 EPNdB on the 500-ft sideline. PNLT time history comparison between BPR=9.4 and 5.7 is shown in Fig. 9(b). At the FAR-36 locations, the EPNL is 95.2 EPNdB (Stage $3-2.1$ ) on the takeoff sideline and 90.2 EPNdB (Stage $3-7.1$ ) at takeoff flyover; again the approach noise would be controlled by turbomachinery noise.

Given that this is a STOL airplane that climbs quickly and descends steeply (likely at a reduced throttle setting as well), there would be a chance that the airplane might be significantly below the Stage 3 rule's flyover and approach limits. This feature may go a long way in satisfying the Stage 4 requirements that the airplane be (re Stage 3 limits): $-10 \mathrm{EPNdB}$, cumulative over all three points; and that it be $-2 \mathrm{EPNdB}$, cumulative over any two points (which would likely be the flyover and approach points). Since the aircraft is about 6 EPNdB below the Stage 3 sideline limit and Stage 4 rules do not allow trades, another cumulative 4 EPNdB reduction at the other points (which should be quite feasible) would be needed for overall Stage 4 certification. Since the jet noise levels were still significant, further large reductions should be possible as was described during the review of Reference 12 .

Specifically, it was determined that the powered lift was not needed after lift off and the take-off field length was significantly shorter than the $5,000 \mathrm{ft}$ target. Thus the IBF noise could be eliminated and the thrust reduced from a lower total loading and use of cutback at the flyover noise point. Trade studies would be needed to optimize for minimum penalty for very low noise. Based on this analysis, aircraft of this type clearly have the potential with further development to offer a relatively quiet approach to utilizing smaller, more noise sensitive airports to relieve congestion and enable growth.

\section{Discussion}

To enable design and evaluation of the current CESTOL vehicle, a number of foundational technologies are needed and are shown in Fig. 10. Some of these technologies are noise shielding codes to accurately predict noise characteristics, quiet powered lift using low pressure IBF, flow control to minimize inlet distortion, etc. In addition to the vehicle airframe innovation, fuel efficient low noise engines are also required to achieve very quiet operation around the airport communities. For the current CESTOL-BWB configuration, it is highly feasible to substitute 12 small conventional engines with a number of high BPR multi-fan engines where one engine core drives a number of fans as shown in Fig. 11. The lateral fans attached to the center core engine could be driven mechanically through gearing system, fluidically using engine core gas, or electrically with core driven generator and distributed motors.

\section{Conclusion}

A system study was conducted to explore the potential benefits from incorporating embedded distributed propulsion systems into a cruise efficient airplane in order to enable quiet operations from small regional airports. As the starting point, the Blended-Wing-Body or BWB configuration was adopted because of its inherent cruise efficiency, low noise characteristics, and large internal volume for embedding engines. The concept is a high-lift capable airframe with partially embedded distributed propulsion system that takes synergistic approach in propulsion-airframe-integration (PAI) by fully integrating airframe and propulsion systems to achieve the benefits of both low-noise STOL operations and efficient high speed cruise. A summary of the recent study is presented on a novel distributed propulsion/airframe configuration that provides low-noise STOL operation to enable 24-hour use of the untapped regional and city-center airports to increase the capacity of the overall airspace while still maintaining efficient high subsonic cruise flight capability. 


\section{References}

1. Grow, H., "Aircraft Wing with Internal Flow Control Propulsion," United States Patent \#4,026,500, 1977.

2. Rulis, R.J., "STOL Noise Sources and Fan Noise Treatment," NASA SP-311, pp. 259-290, May 1972.

3. Kim, H.D. and Saunders, J.D, "Embedded Wing Propulsion Conceptual Study", NATO RTA Symposium on Vehicle Propulsion Integration, RTO-MP-AVT-100, October 2003.

4. Boeing Commercial Airplanes, 2005 Current Market Outlook, URL: http://www.boeing.com.

5. Welge, H., Johng, M., and Gregg, R., "Regional Jet Operational Improvements Resulting from Short Field Performance and Design," AIAA 2003-2891, July 2003.

6. Liebeck, R.H., "Design of the Blended-Wing-Body Subsonic Transport," AIAA-2002-0002, January 2002.

7. Hill, G.A. and Thomas, R.H., "Challenges and Opportunities for Noise Reduction through Advanced Aircraft Propulsion Airframe Integration and Configurations," 8th CEAS Workshop: Aeroacoustics of New Aircraft and Engine Configurations, Budapest, Hungary, 2004.

8. Manneville, A., Pilczer, D., and Spakovszky, Z.S., "Noise Reduction Assessments and Preliminary Design Implications for a Functionally-Silent Aircraft," AIAA 2004-2925, May 2004.

9. Greener by Design, URL: http://www.greenerbydesign.org.uk [cited 26 July 2006]

10. The Silent Aircraft Initiative, URL: http://www.cambridge-mit.org/research/sai [cited 26 July 2006]

11. Wimpress, J.K. and Newberry, C.F., "The YC-14 STOL Prototype: Its Design, Development, and Flight Test," AIAA Case Study, 1998.

12. Kawai, R., "Quiet Cruise Efficient Short Take-Off and Landing Subsonic System," Boeing Technology Phantom Works, Huntington Beach, CA, Report to NASA Glenn Research Center, Contract NAS301140, Task Order \#28, NASA CR-2006- to be published, 2006.

13. Wakayama, S., Kroo, L., "Subsonic Wing Planform Design Using Multidisciplinary Optimization," Journal of Aircraft, Vol. 32, No. 4, Jul.-Aug. 1995, pp.746-753.

14. Stone, J.R., Krejsa, E.A., Berton, J.J. and Kim, H.D., "Initial Noise Assessment of an Embedded-WingPropulsion Concept Vehicle," AIAA-2006-4979, July 2006.

15. Lytle, J.K., "The Numerical Propulsion System Simulation: An Overview,” NASA/TM-2000-209915.

\begin{tabular}{|l|c|c|c|}
\hline & $3,000 \mathrm{nmi}$ Mission & $500 \mathrm{nmi}$ Mission & $150 \mathrm{nmi}$ Mission \\
\hline Range (nmi) & 3,000 & 500 & 150 \\
\hline Payload (lb) & 40,000 & 40,000 & 40,000 \\
\hline Take-off Gross Weight (lb) & 189,140 & 157,874 & 152,835 \\
\hline Total Fuel (lb) & 44,098 & 12,832 & 8,793 \\
\hline Block Fuel (lb) & 37,723 & 7,946 & 4,098 \\
\hline Block Time (hr) & 6.92 & 1.48 & 0.68 \\
\hline Initial Cruise Altitude (ft) & 39,000 & 43,000 & 31,000 \\
\hline Take-off Field Length (ft) & 2,452 & 1,772 & 1,694 \\
\hline Landing Field Length (ft) & 3,477 & 3,457 & 3,454 \\
\hline Take-off $\mathrm{C}_{\mathrm{LMAX}}$ Lift-off & 1.66 & 1.80 & 1.83 \\
\hline Take-off $\mathrm{C}_{\mathrm{LMAX}}$ Obstacle & 1.57 & 1.65 & 1.66 \\
\hline Landing $\mathrm{C}_{\text {LMAX }}$ & 1.06 & 1.06 & 1.06 \\
\hline
\end{tabular}

Table 1. Cruise Efficient Short Take-Off and Landing (CESTOL) vehicle sizing and mission performance. 


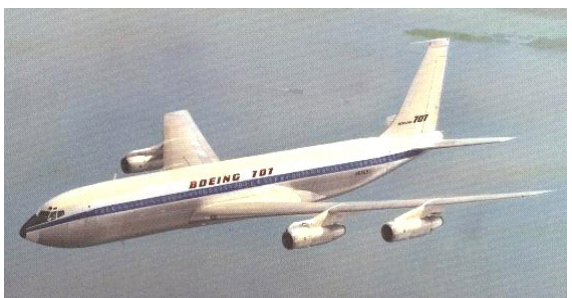

Boeing 707

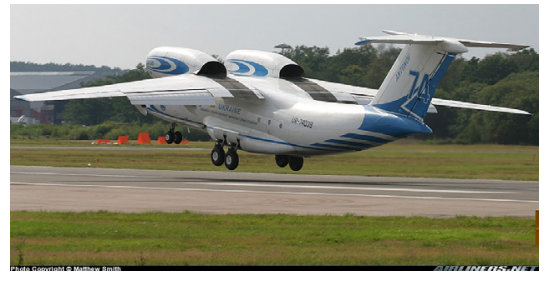

An-74

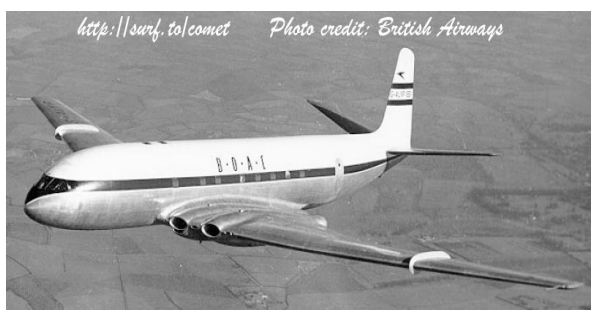

De Havilland Comet

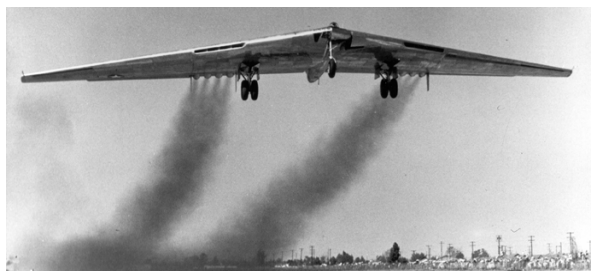

Northrop YB-49

Figure 1 - Some early aircrafts with various propulsion system placements.

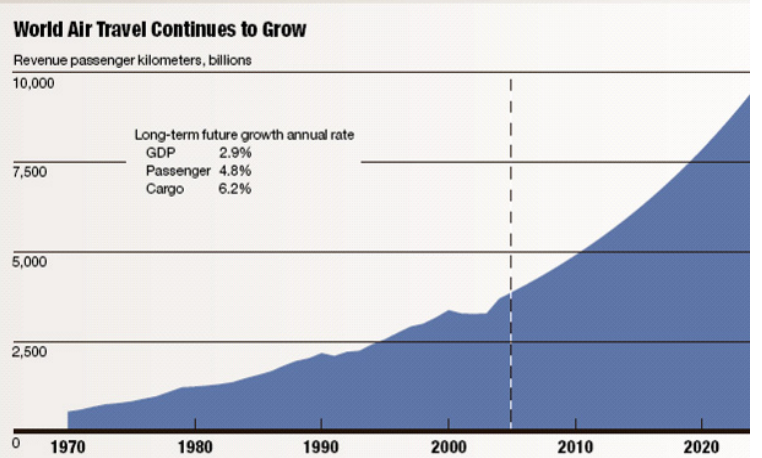

(a) World air travel forecast

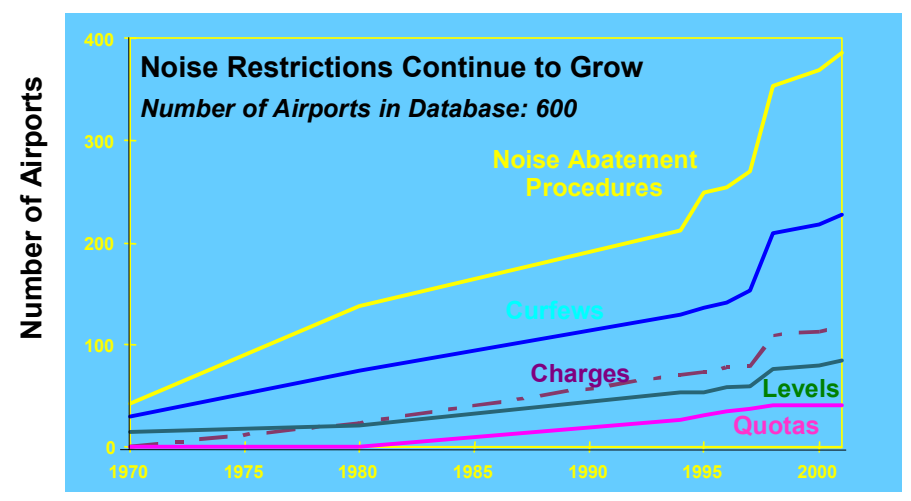

(b) Airport noise restrictions

Figure 2 - From Boeing's 2005 Current Market Outlook. ${ }^{4}$

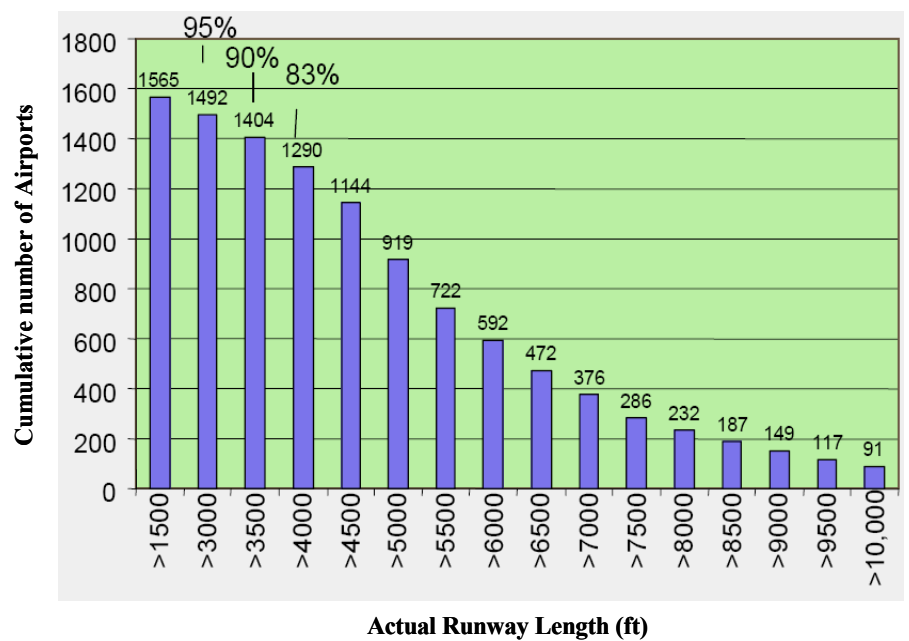

Actual Runway Length (ft)

Figure 3 - US airport distribution with respect to actual runway length. ${ }^{5}$ 


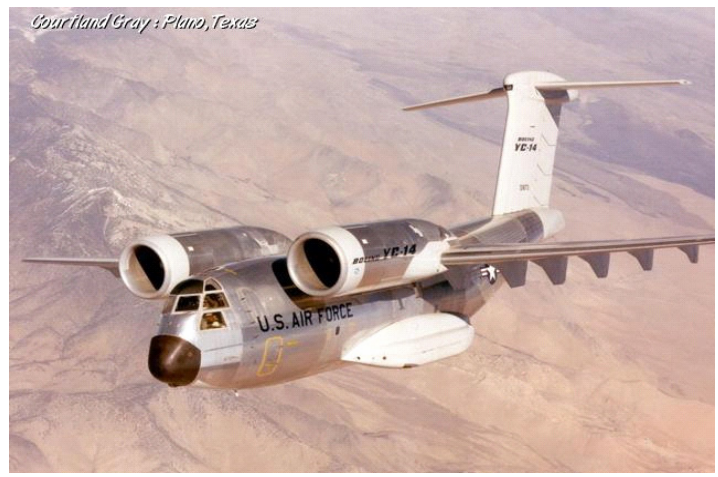

(a) Boeing YC-14

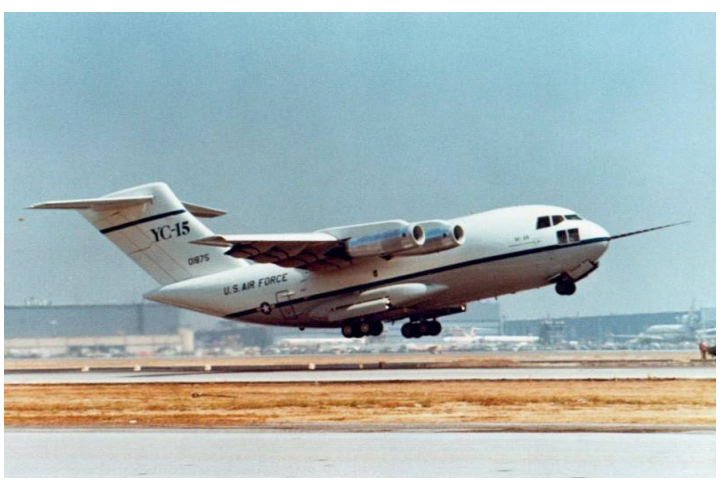

(b) McDonnell-Douglas YC-15

Figure 4 - Air Force prototype competition for the Advanced Medium STOL Transport (AMST).

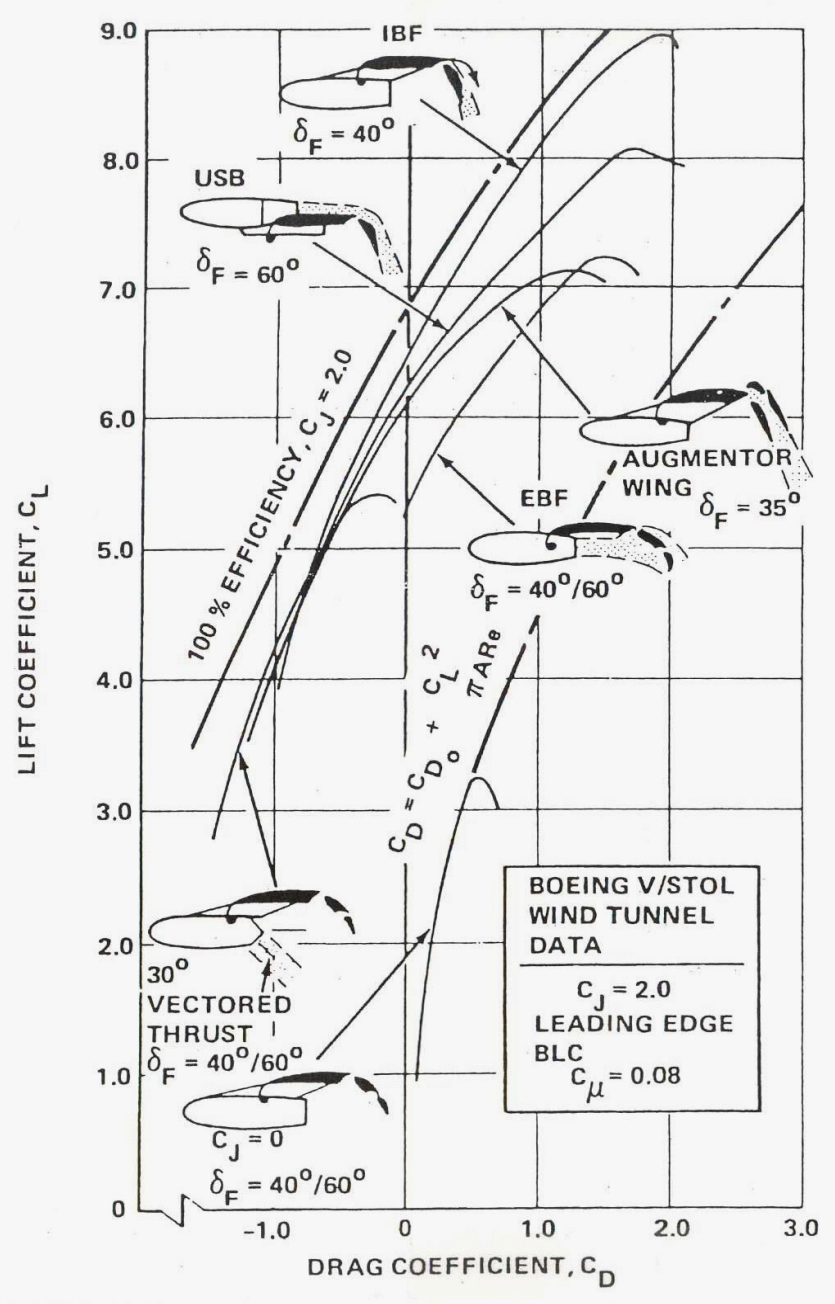

Figure 5 - Comparison of powered lift concepts. ${ }^{11}$ 


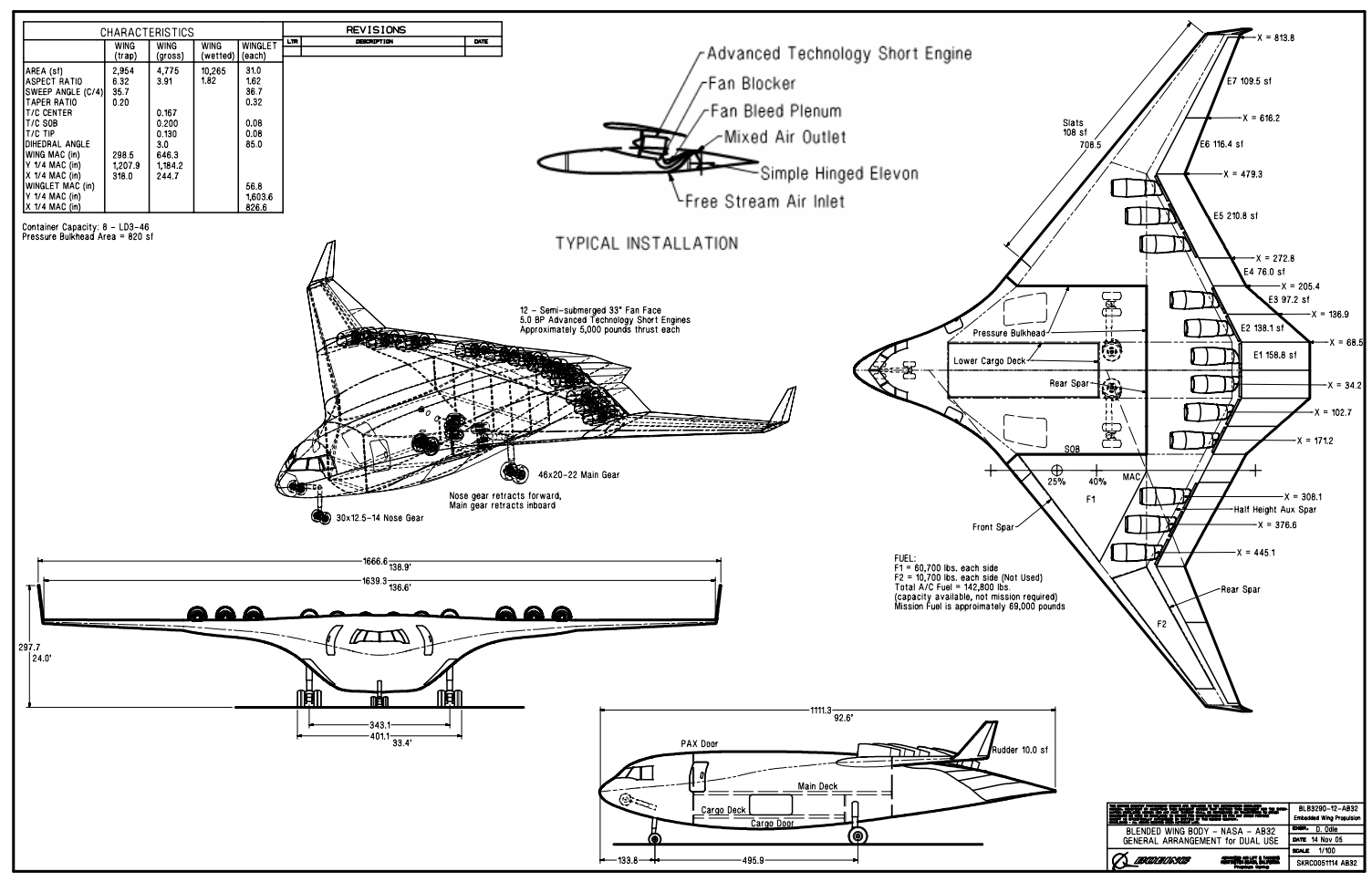

Figure 6 - Cruise Efficient Short Take-Off and Landing (CESTOL) vehicle configuration.

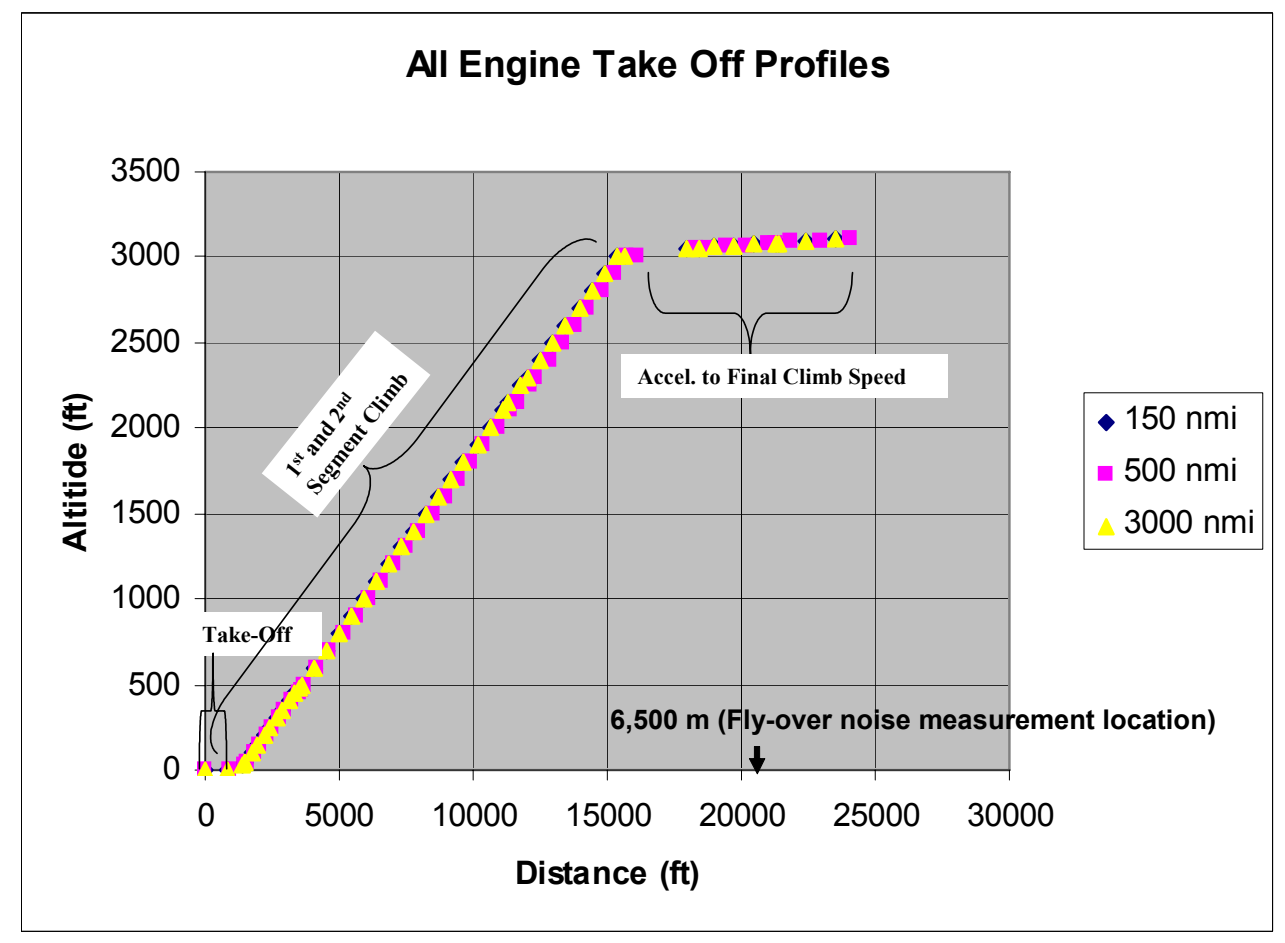

Figure 7 - Cruise Efficient Short Take-Off and Landing (CESTOL) vehicle take-off profiles. 


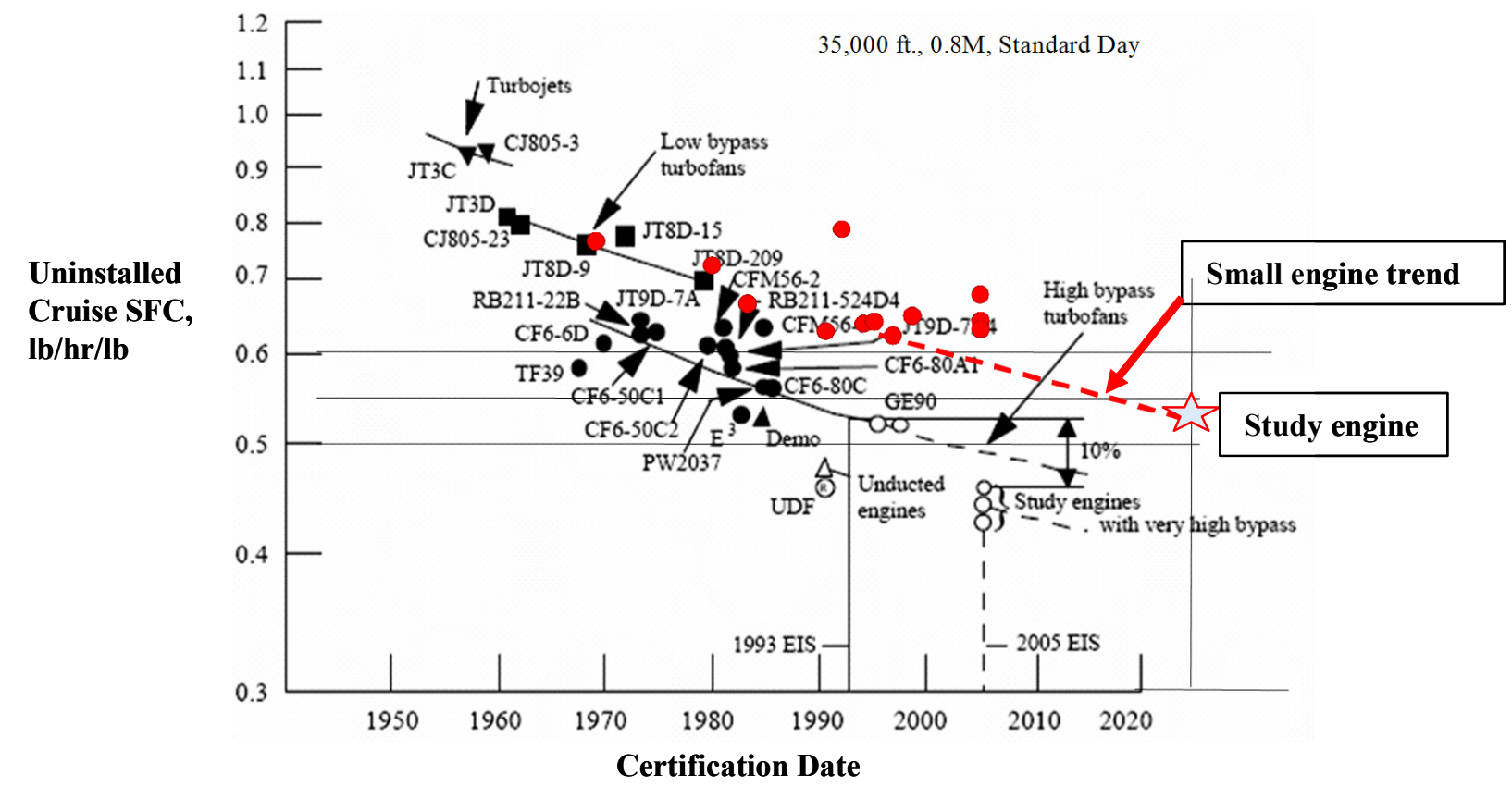

Figure 8 - Specific fuel consumption (SFC) trends in subsonic aircraft engines.

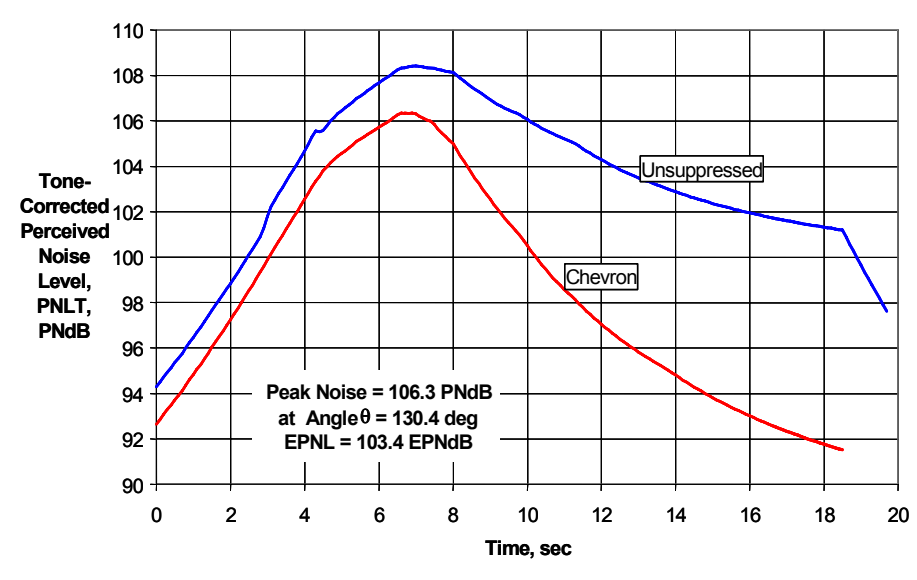

(a)

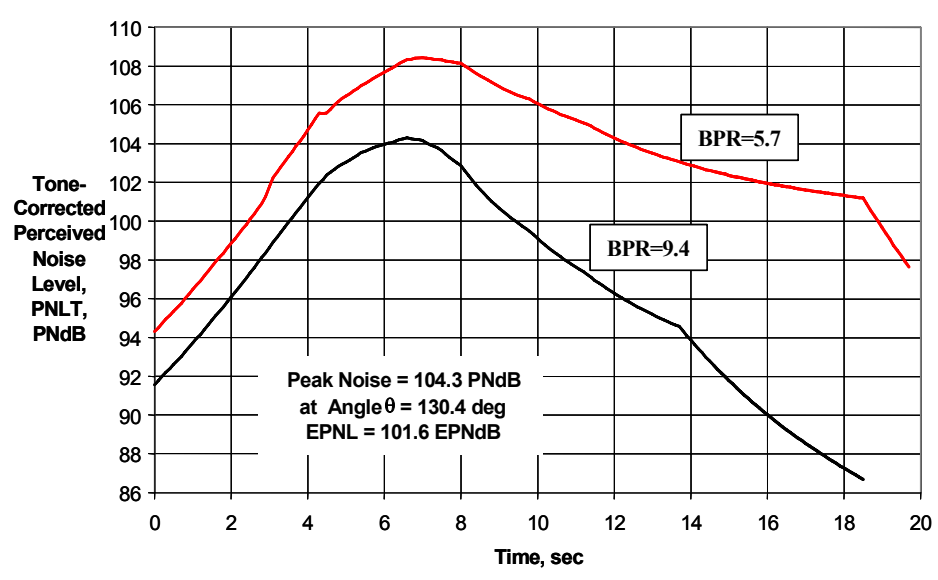

(b)

Figure 9 - PNLT Time History for BWB/IBF Airplane at take-off on 500-ft sideline (a) with engine BPR = 5.7, for chevron nozzles compared to unsuppressed (b) with chevron nozzles, for BPR=9.4 compared to unsuppressed engine $\mathrm{BPR}=5.7$. 


\section{Foundational Technologies Needed}
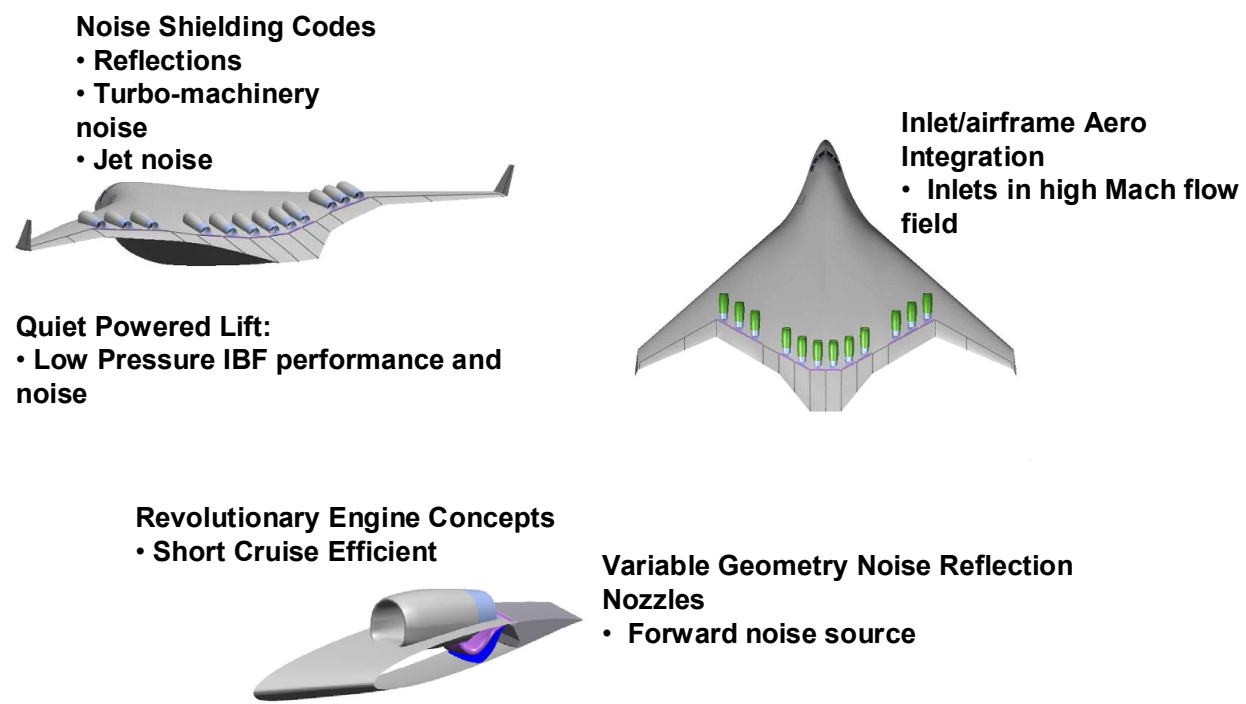

Flow Control Inlets

- Active, Passive and Hybrid

Evaluations

Figure 10 - Foundational technologies needed for low noise CESTOL vehicle.

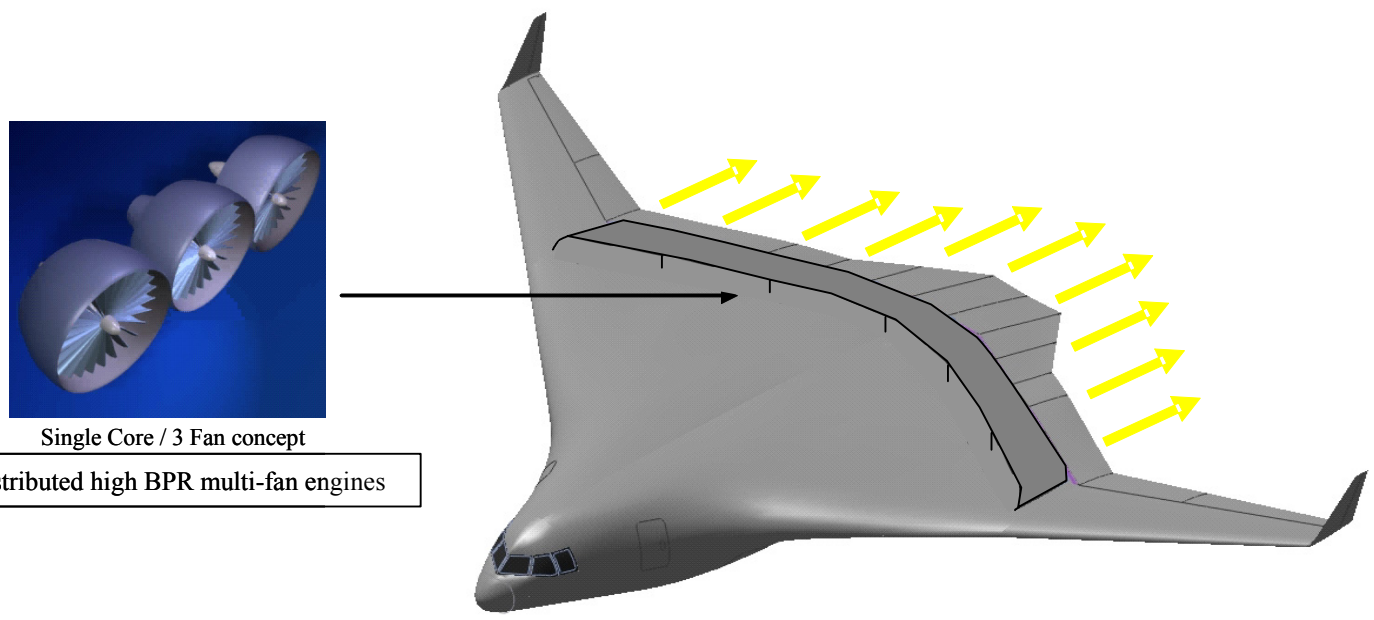

Figure 11 - A notional CESTOL vehicle with distributed high by-pass ratio multi-fan engines. 


\begin{tabular}{|c|c|c|}
\hline \multicolumn{2}{|c|}{ REPORT DOCUMENTATION PAGE } & $\begin{array}{l}\text { Form Approved } \\
\text { OMB No. 0704-0188 }\end{array}$ \\
\hline \multicolumn{3}{|c|}{$\begin{array}{l}\text { Public reporting burden for this collection of information is estimated to average } 1 \text { hour per response, including the time for reviewing instructions, searching existing data sources } \\
\text { gathering and maintaining the data needed, and completing and reviewing the collection of information. Send comments regarding this burden estimate or any other aspect of thi } \\
\text { collection of information, including suggestions for reducing this burden, to Washington Headquarters Services, Directorate for Information Operations and Reports, } 1215 \text { Jefferson } \\
\text { Davis Highway, Suite 1204, Arlington, VA 22202-4302, and to the Office of Management and Budget, Paperwork Reduction Project (0704-0188), Washington, DC 20503. }\end{array}$} \\
\hline 1. AGENCY USE ONLY (Leave blank) & $\begin{array}{l}\text { 2. REPORT DATE } \\
\text { February } 2007\end{array}$ & $\begin{array}{l}\text { ID DATES COVERED } \\
\text { echnical Memorandum }\end{array}$ \\
\hline \multicolumn{3}{|c|}{ Low Noise Cruise Efficient Short Take-Off and Landing Transport Vehicle Study } \\
\hline \multicolumn{2}{|c|}{$\begin{array}{l}\text { 6. AUTHOR(S) } \\
\text { Hyun D. Kim, Jeffrey J. Berton, and Scott M. Jones }\end{array}$} & WBS 561581.02.08.03.07.01 \\
\hline $\begin{array}{l}\text { 9. SPONSORING/MONITORING AGEI } \\
\text { National Aeronautics and Sp } \\
\text { Washington, DC 20546-00 }\end{array}$ & $\begin{array}{l}\text { NAME(S) AND ADDRESS(ES) } \\
\text { Administration }\end{array}$ & $\begin{array}{l}\text { 10. SPONSORING/MONITORING } \\
\text { AGENCY REPORT NUMBER } \\
\text { NASA TM-2007-214659 } \\
\text { AIAA-2006-7738 }\end{array}$ \\
\hline
\end{tabular}

Prepared for the Sixth Aviation Technology, Integration and Operations Conference (ATIO) sponsored by the American Institute of Aeronautics and Astronautics, Wichita, Kansas, September 25-27, 2006. Responsible person, Hyun D. Kim, organization code PBA, 216-433-8344.

\begin{tabular}{|l|l|}
\hline 12a. DISTRIBUTION/AVAILABILITY STATEMENT & 12b. DISTRIBUTION CODE
\end{tabular}

Unclassified - Unlimited

Subject Category: 05

Available electronically at http://gltrs.grc.nasa.gov

This publication is available from the NASA Center for AeroSpace Information, 301-621-0390.

13. ABSTRACT (Maximum 200 words)

The saturation of the airspace around current airports combined with increasingly stringent community noise limits represents a serious impediment to growth in world aviation travel. Breakthrough concepts that both increase throughput and reduce noise impacts are required to enable growth in aviation markets. Concepts with a 25 year horizon must facilitate a $4 \mathrm{x}$ increase in air travel while simultaneously meeting community noise constraints. Attacking these horizon issues holistically is the concept study of a Cruise Efficient Short Take-Off and Landing (CESTOL) high subsonic transport under the NASA's Revolutionary Systems Concepts for Aeronautics (RSCA) project. The concept is a high-lift capable airframe with a partially embedded distributed propulsion system that takes a synergistic approach in propulsionairframe-integration (PAI) by fully integrating the airframe and propulsion systems to achieve the benefits of both lownoise short take-off and landing (STOL) operations and efficient high speed cruise. This paper presents a summary of the recent study of a distributed propulsion/airframe configuration that provides low-noise STOL operation to enable 24-hour use of the untapped regional and city-center airports to increase the capacity of the overall airspace while still maintaining efficient high subsonic cruise flight capability.

\begin{tabular}{|l|l|l|}
\hline $\begin{array}{l}\text { 14. SUBJECT TERMS } \\
\text { Distributed propulsion; STOL }\end{array}$ \\
\begin{tabular}{c|c} 
17. SECURITY CLASSIFICATION \\
OF REPORT \\
Unclassified
\end{tabular} & $\begin{array}{c}\text { 18. SECURITY CLASSIFICATION } \\
\text { OF THIS PAGE } \\
\text { Unclassified }\end{array}$ & $\begin{array}{c}\text { 19. SECURITY CLASSIFICATION } \\
\text { OF ABSTRACT } \\
\text { Unclassified }\end{array}$ \\
\hline
\end{tabular}

NSN 7540-01-280-5500

Standard Form 298 (Rev. 2-89)

Prescribed by ANSI Std. Z39-18 298-102 

